\begin{tabular}{|c|c|c|c|c|c|c|}
\hline \multirow{4}{*}{ Impact Factor: } & ISRA (India) & $=3.117$ & SIS (USA) & $=0.912$ & ICV (Poland) & $=6.630$ \\
\hline & ISI (Dubai, UAE & $=0.829$ & РИНЦ (Russia & $=0.156$ & PIF (India) & $=1.940$ \\
\hline & GIF (Australia) & $=0.564$ & ESJI (KZ) & $=8.716$ & IBI (India) & $=4.260$ \\
\hline & JIF & $=1.500$ & SJIF (Morocco & $=5.667$ & OAJI (USA) & $=0.350$ \\
\hline
\end{tabular}

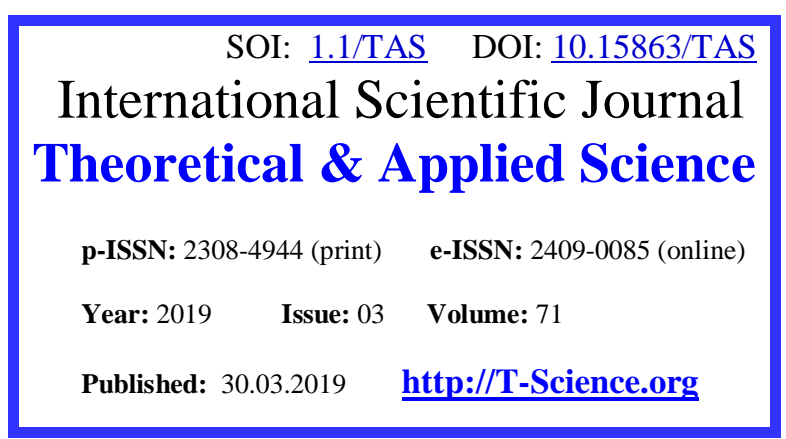

SECTION 31. Economic research, finance, innovation, risk management.
QR - Issue

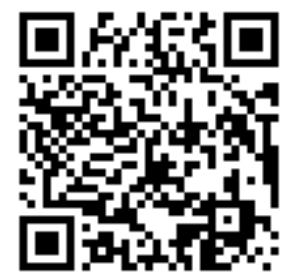

QR - Article

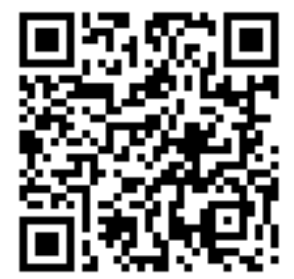

Fatima Tulkunovna Kasimova

PhD, Tashkent Chemical Technology Institute,

Tashkent, Republic of Uzbekistan

\title{
IMPROVEMENT OF MARKETING ACTIVITIES IN SMALL ENTREPRENEURSHIP IN THE CONDITIONS OF DEVELOPMENT OF COMPETITIVE MARKETS
}

Abstract: The article discusses the improvement of marketing activities in small business in the development of competitive markets. The author has improved the system of indicators, evaluating the effectiveness of the marketing strategy taking into account changes in profits, market share, number of competitors, with the selection of segments of strategic business areas of small businesses.

Key words: marketing, competitiveness, market, market relations, strategy.

Language: English

Citation: Kasimova, F. T. (2019). Improvement of marketing activities in small entrepreneurship in the conditions of development of competitive markets. ISJ Theoretical \& Applied Science, 03 (71), 577-583.

Soi: http://s-o-i.org/1.1/TAS-03-71-58 Doi: crossef https://dx.doi.org/10.15863/TAS.2019.03.71.58

\section{Introduction}

Small business all over the world is considered as the most important basis for the effective functioning and development of the national economy. Small business can effectively contribute to the growth of employment in the republic and its regions, promote the formation of a competitive environment and its saturation of the market with consumer goods, as well as ensure the revitalization of innovation activities. In many countries of the world, small business development institutes have been established, in particular in the USA (STTR-Small Business Technology Transfer, SBIR-Small Business Innovation Research Program), Canada (IRAPIndustrial Research Assistance Program), Israel (Yozma), Great Britain (SBIC- Small Business Investment Companies Program) and other countries. They have developed marketing research programs in small business, focused on the possibility of their rapid adaptation to the changing market environment. In modern conditions, increased attention to the development of small business and private entrepreneurship is due to their influence on the dynamics of the socio-economic development of the country. The share of small businesses in 2016 in gross domestic product in developed countries in Japan was $(55 \%)$, respectively in the United States $(52 \%)$, France $(50 \%)$ and Germany $(47 \%)$.
Today, on a global scale, in order to improve state support for small businesses and private entrepreneurship, to stimulate innovative activities of business entities, research is being conducted in such priority areas as assessing the impact of economic mechanisms on the development of innovative entrepreneurship, increasing the transparency and attractiveness of the business environment, developing a small business support system based marketing approach.

\section{Literature review}

Scientific-theoretical and methodological aspects of marketing research and improving the competitiveness of business entities are considered in the works of such foreign scientists as F.Kotler, M.Porter, J. Egan, P. Doyle, N.K. Malhotra, M. Stone, N. Woodcock, L. Machtinger, J. O'Shaughnessy, and others. [1-5]

In the CIS countries, some areas of increasing the competitiveness of small businesses are reflected in the scientific works of M. Afans'eva, V. Belyaev, A. Godin, N. Grishina, N. Nosova, A. Koreneva, I. Kozieva, N. Popova, R. Fatkhutdinova and others. [69]

General aspects of the improvement of the marketing system and the most important issues of marketing research, the growth of competitiveness of 


\begin{tabular}{|c|c|c|c|c|c|c|}
\hline \multirow{4}{*}{ Impact Factor: } & ISRA (India) & $=3.117$ & SIS (USA) & $=0.912$ & ICV (Poland) & $=6.630$ \\
\hline & ISI (Dubai, UAE & $=0.829$ & РИНЦ (Russia & $=0.156$ & PIF (India) & $=1.940$ \\
\hline & GIF (Australia) & $=0.564$ & ESJI (KZ) & $=8.716$ & IBI (India) & $=4.260$ \\
\hline & JIF & $=1.500$ & SJIF (Morocco & $=5.667$ & OAJI (USA) & $=0.350$ \\
\hline
\end{tabular}

industrial enterprises in Uzbekistan are reflected in the scientific studies of such domestic scientists as A.Sh.Bekmurodov, M.R.R.Boltabaev, Sh.D.Ergashhodzhaeva, A.A. Fattakhov, D.M. Mukhitdinov, M.A.Ikramov, G.N.Akhunova, G.Kariev, G.Ostonakulov, N.A.Alimhodzhaeva, A.Tillakhodzhaev, Z.Hakimov, Tursunov B. and others. [10-14]

Meanwhile, the problems of marketing research in the field of small business and private entrepreneurship have not been fully studied. As is known from the experience of world practice, the field of small business is one of the priority directions of development of the national economy.

The relevance of the problem, its practical significance, the lack of knowledge of the features of the methodology of marketing research in small business in the context of growing competitive markets determined the choice of the topic of dissertation work.

The study determined the essential features of the current global trends in the development of the marketing system in small business in the context of globalization. It is substantiated that the potential of small business in the Republic of Uzbekistan is shaped by various factors and conditions identified in the international rating assessments of the business environment (the position of Uzbekistan in 2017 improved in 5 of 10 indicators of the report, "Doing business" including property, building permits, etc.). Based on this, the author made a systematization and classification of factors influencing the formation and realization of the potential of small business and private entrepreneurship in the Republic of Uzbekistan, taking into account the marketing concepts of business development.

The generalization of existing in practice methods and tools for the formation of the marketing system in small business, allowed to identify the following problems:

in management: low managerial level, lack of special knowledge and experience of market relations, insufficient level of personnel management, etc .;

in infrastructure: the full infrastructure for the development of small business is underdeveloped (especially in rural areas): connection to engineering and communication systems, level of information support, etc ;

in institutions: insufficient level of consulting support for small businesses, underdevelopment of the public-private partnership system, low use of franchising, outsourcing, cooperation, etc .;

in market conditions: fierce competition due to the large number of business entities of small business and private entrepreneurship (for example, on $01 / 01 / 2018$, the number of operating small business entities was 229.7 thousand units against 213.6 thousand units in 2014 their growth reached $107.5 \%$ ), pressure on the import market, etc.; in the use of marketing: lack of complete and reliable information about the state and market conditions, the inability to focus on one product development model, limited opportunities in the study of export market opportunities and the creation of specialized marketing services, etc.

The results of the strategic analysis of the institutional framework for the development of marketing activities in small businesses led to the need to form a new approach to marketing management in small businesses.

Summarizing the various methodological approaches of domestic and world practice with the evaluation of the marketing system for small businesses, the work offered tools for assessing their market positions and a system of indicators for assessing their competitiveness in the market (based on the use of marketing mix methods).

In Uzbekistan in recent years there have been significant changes in the development of small business and private entrepreneurship. The results of the study showed that government support for small businesses contributes to the growth of its share in the macroeconomic parameters of the country.

As the analysis showed, in 2016 the share of small business and private entrepreneurship (IBPP) in the gross domestic product (GDP) was $56.9 \%$ against $54.0 \%$, in 2011 its growth was 2.9 points. Over the analyzed period, the share of IBPs in the volume of investments in fixed assets increased significantly to $39.1 \%$ (against $31.9 \%$ in 2011), in the export of goods and services $26.5 \%$ (against $18.8 \%$ ) and the number of employed in the economy was $78.2 \%$ (versus $75.1 \%)$.

Indicators of small business development in the Republic of Uzbekistan at the present stage indicate its high economic potential. However, according to the author, if previously the main criteria for its development were, above all, the size and concentration of capital, the volume of trade, industrial potential and employment, then, in recent years, marketing components that correspond to global trends have come to the first place.

It should be noted that today the opinion of consumers about the product, its position in the market, information about competitors and effective pricing policy are the determining components of the marketing activities of small businesses. However, if large enterprises are willing to spend significant resources on control of the marketing situation, then small enterprises are practically deprived of this opportunity and are limited to survey methods.

In the course of the study, the most effective marketing management tools were identified, and their role in the system of developing and implementing a company development strategy was determined. I. Ansoff believes that the analysis of the competitive status of the enterprise through the use of marketing tools and methods sets the following goals: 


\begin{tabular}{|c|c|c|c|c|c|c|}
\hline \multirow{4}{*}{ Impact Factor: } & ISRA (India) & $=3.117$ & SIS (USA) & $=0.912$ & ICV (Poland) & $=6.630$ \\
\hline & ISI (Dubai, UAE & $=0.829$ & РИНЦ (Russia) & $=0.156$ & PIF (India) & $=1.940$ \\
\hline & GIF (Australia) & $=0.564$ & ESJI (KZ) & $=8.716$ & IBI (India) & $=4.260$ \\
\hline & JIF & $=1.500$ & SJIF (Morocco & $=5.667$ & OAJI (USA) & $=0.350$ \\
\hline
\end{tabular}

the development of a strategy and the determination of the opportunities and resources that the enterprise needs to select in order to concentrate them in strategic economic zones (SZH);

distribution of resources between $\mathrm{SZH}$ in the short term.

Based on this, the paper developed a methodical approach to the development of a marketing strategy, with the definition of appropriate SZH using sociological research on the example of the company Mavis Global LLC. The representativeness of the research object is confirmed by the fact that Mavis Global LLC is a small enterprise (less than 110 employees), its share in the local confectionery market in 2017 exceeded 35\%. As the analysis showed, the company for 2014-2016. spent more than $10 \%$ of the total cost of marketing research and advertising campaigns.

As part of this study, the author in 2016 developed and implemented a technology for integrating survey methods into the activities of the company Mavis Global LLC, which includes all stages of marketing - from packaging, assortment to display at the points of sale of goods. The development was based on the 4P marketing concept (place, press, promotion, product), taking into account the use of the concept of defining strategic business areas $(\mathrm{SZH})$.

The developed methodology for organizing the marketing of a small enterprise is based on the segmentation of the strategic areas of a small enterprise, taking into account the specifics of its production activities and the peculiarities of the functioning of the confectionery market (Fig. 2).

According to the results of a sociological study, the features of data collection and integration of survey methods were identified to increase the effectiveness of marketing activities of Mavis Global LLC, according to the following components:

Place (within the framework of the strategic planning area) is proposed to be implemented through an assessment of the competitive position (competitors) of the company in the market;

The term (within the framework of the strategic economic management zone "financial administration"), the survey methods were laid down to study the pricing policy (determining the market position and competitiveness of the price of goods);

promotion (within the framework of the strategic zone of management "promotion") it was proposed to use new methods of advertising technologies - POS (point of sale). Testing this technology at Mavis Global LLC (the packaging of goods was changed with a focus on the brand and a new POS management concept was implemented) in 2017 gave a profit increase of $7.1 \%$;

product (in the framework of the strategic distribution zone "distribution") a process was proposed to systematize the control of product positioning (production volume, range, brand awareness, packaging, etc.) and distribution coverage.

As the results of the study show, the main difference from the traditional marketing activities of small businesses is that the introduction of the marketing mix methods (4P) will make it possible to use innovative, personnel, investment and other components of the business potential, taking into account the peculiarities of the formation of competitive markets.

Thus, an integrated method of data collection has been formed, based on surveys, with the creation of a single database of functioning small business entities that show not only the general situation on the market, but are also a real tool for diagnosing and forming a competitive strategy.

The proposed research methodology allowed the author to obtain a comparative assessment of Mavis Global's positions against major players in the market and determine competitive advantages in certain areas, as well as evaluate each segment in terms of its growth or decline against changes in the confectionery market (Table. 2).

As the analysis of the confectionery market showed, the company Roshen significantly reduced its position in 2017 relative to 2016 , when it was a clear leader, in 2017 the Rahat brand became the leader in this segment. Mavis Global LLC also increased its market share by $5.7 \%$, taking up $6.4 \%$ of its share. However, in 2017, such large imported trademarks as Roshen and Rahat remain the main players and competitors of other players in the caramel candy segment. The dissertation research substantiates the need to highlight the priority areas of assortment policy development, which are purposeful activities related to planning a set of measures to create competitive advantages of products and taking into account consumer preferences, allowing efficient use of the resources of Mavis Global LLC related to the adaptation of production to production of competitive products.

Table 1. Changes in the market share of the trade marks of Mavis Global LLC for 2015-2017.

\begin{tabular}{|c|c|c|c|c|c|c|}
\hline \multirow[b]{2}{*}{ Trade marl } & \multicolumn{3}{|c|}{ Market share, \% } & \multicolumn{2}{|c|}{ Growth $(+),(-)$} & \multirow{2}{*}{$\begin{array}{c}\text { Mean rate of } \\
\text { market } \\
\text { share, } \% \\
\end{array}$} \\
\hline & $2015 y$ & $2016 y$ & 2017Y & $\begin{array}{l}\text { In } 2017 y \text {. to } \\
2015 y .\end{array}$ & $\begin{array}{c}\text { In 2016y. to } \\
2015 y \text {. }\end{array}$ & \\
\hline Roshen & 56,8 & 75,6 & 20,0 & $-36,8$ & $-18,8$ & 50,8 \\
\hline Рахат & 14,0 & 12,0 & 32,5 & $+18,5$ & $+2,0$ & 19,5 \\
\hline
\end{tabular}




\begin{tabular}{|c|c|c|c|c|c|c|}
\hline \multirow{4}{*}{ Impact Factor: } & ISRA (India) & $=\mathbf{3 . 1 1 7}$ & SIS (USA) & $=0.912$ & ICV (Poland) & $=6.630$ \\
\hline & ISI (Dubai, UAE & $=0.829$ & РИНЦ (Russia & $=0.156$ & PIF (India) & $=1.940$ \\
\hline & GIF (Australia) & $=0.564$ & ESJI (KZ) & $=8.716$ & IBI (India) & $=4.260$ \\
\hline & JIF & $=1.500$ & SJIF (Morocco & $=5.667$ & OAJI (USA) & $=0.350$ \\
\hline
\end{tabular}

\begin{tabular}{|c|c|c|c|c|c|c|}
\hline Konti & 11,0 & 5,0 & 11,0 & - & $-6,0$ & 9,0 \\
\hline Miezsko & 2,0 & 2,0 & 5,0 & $+3,0$ & - & 3,0 \\
\hline BayanSulu & 3,0 & 1,3 & 4,6 & +1.6 & $-1,7$ & 3,0 \\
\hline Rot Front & 2,8 & 1,3 & 4,0 & $+1,2$ & -1.5 & 2,7 \\
\hline Mavis & 3,0 & 0,7 & 6,4 & $+3,4$ & -2.3 & 3,4 \\
\hline Enjoyment & 1,5 & 5,0 & 7,0 & $+5,5$ & $+3,5$ & 4,5 \\
\hline Kharkov & 1,6 & 2,0 & 2,0 & 0,4 & $+0,4$ & 1,8 \\
\hline Drugie & 2,1 & 1,7 & 2,3 & $+0,2$ & $-0,4$ & 2,0 \\
\hline Zebiniso & 2,3 & 1,0 & 1,0 & $-1,3$ & -1.3 & 1,4 \\
\hline Shirinasal & 1,2 & $\mathbf{1 , 0 8}$ & 1,0 & $-0,2$ & $-0,1$ & 1,1 \\
\hline
\end{tabular}

Source: author`s development

Table 3 presents the main product line of production of LLC Mavis Global, as well as sales in quantitative terms for the years 2015-2017. It should be noted that after the rebranding, carried out on the basis of the marketing research method proposed by the author, chocolate paste received an increase in sales in 2017 over 2016 from 2016 more than 2.7 times.

Table 2. Dynamics of sales of the trade mark of LLC Mavis Global by product categories for 2015-2017.

\begin{tabular}{|l|c|c|c|c|c|}
\hline Products & \multirow{2}{*}{$\mathbf{2 0 1 5} \mathbf{y} \cdot$} & $\mathbf{2 0 1 6} \mathbf{y} \cdot$ & \multirow{2}{*}{$\mathbf{2 0 1 7} \mathbf{y} \cdot$} & \multicolumn{2}{|c|}{ Growth, \% } \\
\cline { 5 - 6 } & & & & In 2017r. To 2015 y. & In 2017y. to 2016 y. \\
\hline Caramel & 340,7 & 350,0 & 450,1 & 132,1 & 128,6 \\
\hline Souffle & 751,4 & 63,8 & 87,11 & 115,9 & 136,4 \\
\hline Biscuit & 900,5 & 924,5 & 1119,3 & 124,3 & 121,1 \\
\hline Chocolate paste & 15,0 & 16,0 & 43,6 & 2,9 times & 2.7 times \\
\hline Marshmallow & 147,02 & 136037 & 171,25 & 116,5 & 125,9 \\
\hline Marmalade & 70,9 & 81801 & 127,5 & 179 & 155,8 \\
\hline Domestic market & 1287,7 & 1544,9 & 1720 & 133,6 & 7,2 times \\
\hline Export & - & 40,69 & 296,9 & - & 6,2 times \\
\hline Total & 2837,2 & 3157,9 & 19500,27 & 6,8 times & \\
\hline
\end{tabular}

Source: author`s development

The method proposed by us for improving the organization of marketing research had a positive effect on the sales of such products as soufflé - growth compared to 2016, in 2017 amounted to $128.6 \%$, cookies - 121.1

$\%$, chocolate paste -2.7 times, caramel $-132.1 \%$ and marmalade - $128.6 \%$.

The marketing research tools for survey data proposed in the thesis and their subsequent analysis created the possibility of shaping the portfolio policy of Mavis Global LLC and its focus on the most dynamic product segments, providing an opportunity to release investments in promising areas and optimize operating costs. [15]

The change in competitive methods (branding) has led to a change in the concept of marketing, which today is called "relationship marketing" when it emphasizes the priority of consumers and the need to build these relations. As shown in the work, the holistic system of the organization's activities in the market, relationship marketing will have a great influence on the development of entrepreneurial activity.

First, relationship marketing creates a new way of thinking, which is shaped as a system for optimally adapting the organization's specific goals to real opportunities to achieve them through interaction with the target market.

Secondly, relationship marketing creates a new mode of action for small businesses in the market. A holistic methodology of market activity is being formed, which should provide for a flexible change in product, price, communication, and financial policies depending on market changes and consumer behavior.

Third, relationship marketing allows an organization to achieve a competitive advantage (internal and external) through effective competitive behavior, which provides not only the advantages of products, assortment, pricing, etc., but also creates integrated marketing communications. 


\begin{tabular}{|c|c|c|c|c|c|c|}
\hline \multirow{4}{*}{ Impact Factor: } & ISRA (India) & $=3.117$ & SIS (USA) & $=0.912$ & ICV (Poland) & $=6.630$ \\
\hline & ISI (Dubai, UAE & $=0.829$ & РИНЦ (Russia) & $=0.156$ & PIF (India) & $=1.940$ \\
\hline & GIF (Australia) & $=0.564$ & ESJI (KZ) & $=8.716$ & IBI (India) & $=4.260$ \\
\hline & JIF & $=1.500$ & SJIF (Morocco) & $=5.667$ & OAJI (USA) & $=0.350$ \\
\hline
\end{tabular}

Fourthly, the peculiarity of the modern market is not only that the markets are saturated with goods and brands, among which the consumer must make his choice, but also that the market becomes oversaturated with information.
With this in mind, according to the author, in market conditions, a brand is considered as one of the assets of the organization, and branding is an effective tool for realizing the competitive advantages of a business (Table 3).

Table 3. The dynamics of changes in the parameters of recognition and the possibility of the trade mark Mavis Global LLC for 2016-2017.

\begin{tabular}{|l|c|c|l|}
\hline Recognition parameters & $\mathbf{2 0 1 6} \mathbf{r .}$ & $\mathbf{2 0 1 7} \mathbf{\Gamma}$. & $\begin{array}{l}\text { Dynamics of change of } \\
\text { recognition parameters }\end{array}$ \\
\hline $\begin{array}{l}\text { Knowledge of the brand without prompting (\% of } \\
\text { respondents who answered positively) }\end{array}$ & 13 & 65 & improved by 52\% \\
\hline $\begin{array}{l}\text { Brand knowledge with a hint (\% of respondents who } \\
\text { answered positively) }\end{array}$ & 22 & 75 & improved by 53\% \\
\hline Average trademark trust rating from 1-10 & 2 из 10 & 7 из 10 & improved by 5 points \\
\hline Average brand image rating from 1-10 & 3 из 10 & 8 из 10 & improved by 5 points \\
\hline
\end{tabular}

Source: author's development

The use of Mavis Global LLC an effective brand strategy has given it certain competitive advantages:

The company's brand forces competitors to invest capital in market research and product line upgrades, marketing research, and promotional activities;

the presence of a recognizable brand contributes to the company's ability to update the product line with the introduction of new confectionery products to the market, increasing its share in the republican market and entering foreign markets (including through unique product offerings - souvenir confectionery with the image of tourist attractions in the country's regions); the implementation of a CRM system (Customer Relationship Management) will be aimed at creating an extensive database of "loyal" customers for the brand, which for Mavis Global LLC is a long-term competitive advantage (business strategy based on a customer-oriented approach);

the brand gives Mavis Global LLC the opportunity to reengineer business processes in order to adapt to the conditions of uncertainty and increase competition in the market (both domestically and externally).

One of the results of the study is the evaluation of the effectiveness of the marketing strategy at Mavis Global LLC in the context of growing competitive markets (Table 4).

Table 4. Criteria for evaluating the marketing strategy of Mavis Global LLC in the context of growing competitive markets

\begin{tabular}{|c|c|c|c|c|c|c|c|}
\hline Components & Indicator & $\begin{array}{l}\text { Plan - } \\
\text { target }\end{array}$ & Fact & $\begin{array}{l}\text { Devi } \\
\text { ation }\end{array}$ & $\begin{array}{l}\text { Weighting } \\
\text { factor } \\
\text { (personally } \\
\text { for the } \\
\text { company) }\end{array}$ & $\begin{array}{c}\text { Forecas } \\
\text { t from } 0 \\
\text { to } 1\end{array}$ & $\begin{array}{c}\text { Actual } \\
\text { from } \\
0 \text { to } 1\end{array}$ \\
\hline \multicolumn{8}{|c|}{ Place within the strategic planning area. } \\
\hline competitors & Market share & 65 & 55 & -10 & 1 & 0,8 & 0,8 \\
\hline -sales plan & B SSU* & $\begin{array}{c}500 \\
\text { тыс. }\end{array}$ & $\begin{array}{c}48 \\
\text { тыс. }\end{array}$ & $\begin{array}{c}-2 \\
\text { тыс. }\end{array}$ & 1 & 0,9 & 0,9 \\
\hline $\begin{array}{l}\text { production } \\
\text { plan }\end{array}$ & B SSU* & 66 тыс. & $\begin{array}{c}67 \\
\text { тыс. }\end{array}$ & +1 & 1 & 1 & 1 \\
\hline - stock & B SSU* & 25 тыс. & $\begin{array}{c}25 \\
\text { тыс. }\end{array}$ & 0 & 1 & 1 & 1 \\
\hline \multicolumn{8}{|c|}{ Price in the framework of the strategic management zone "Financial Administration". } \\
\hline - stocks & Change in sales & +12 & +10 & +2 & 0,6 & 0,6 & 0,7 \\
\hline Discounts & $\begin{array}{l}\text { Return on short term ROI } \\
\text { investment. }\end{array}$ & 0,56 & 0,5 & $\begin{array}{c}+0,0 \\
6\end{array}$ & 0,5 & 0,5 & 0,5 \\
\hline
\end{tabular}




\begin{tabular}{|c|c|c|c|c|c|c|}
\hline \multirow{4}{*}{ Impact Factor: } & ISRA (India) & $=3.117$ & SIS (USA) & $=0.912$ & ICV (Poland) & $=6.630$ \\
\hline & ISI (Dubai, UAE & $=0.829$ & РИНЦ (Russia) & $=0.156$ & PIF (India) & $=1.940$ \\
\hline & GIF (Australia) & $=0.564$ & ESJI (KZ) & $=8.716$ & IBI (India) & $=4.260$ \\
\hline & JIF & $=1.500$ & SJIF (Morocco) & $=5.667$ & OAJI (USA) & $=0.350$ \\
\hline
\end{tabular}

\begin{tabular}{|c|c|c|c|c|c|c|c|}
\hline $\begin{array}{l}\text {-competitive } \\
\text { price. }\end{array}$ & $\begin{array}{l}\text { Calculation of competitiveness } \\
\text { index by economic indicators } \\
\text { (I). }\end{array}$ & 95 & 90 & -5 & 0,7 & 0,7 & 0,6 \\
\hline $\begin{array}{l}\text {-profit } \\
\text { company. }\end{array}$ & Change gross margin. & 5 & 10 & -5 & 0,4 & 0,4 & 0,2 \\
\hline \multicolumn{8}{|c|}{ Promotion within the framework of the "Promotion" strategic management zone. } \\
\hline $\begin{array}{l}\text { - } \\
\text { merchandisi } \\
\text { ng }\end{array}$ & $\begin{array}{l}\text { The number of TT. Decorated } \\
\text { according to the standard }\end{array}$ & 87 & 95 & -7 & 0,3 & 0,3 & 0,2 \\
\hline $\begin{array}{l}\text {-marketing } \\
\text { in retail } \\
\text { outlets }\end{array}$ & $\begin{array}{l}\text { The number of exclusive so. to } \\
\text { the total number of } \\
\text { implementation of MT }\end{array}$ & 25 & 22 & -3 & 0,9 & 0,9 & 0,8 \\
\hline $\begin{array}{l}\text { - } \begin{array}{l}\text {-advertising } \\
+\quad \text { POS }\end{array}\end{array}$ & $\begin{array}{l}\text { In\% of competitors by survey } \\
\text { results }\end{array}$ & 95 & 95 & 0 & 0,2 & 0,2 & 0,2 \\
\hline & $\begin{array}{l}\text { Amount t.t. to the total count } \\
\text { th. implementation of MT }\end{array}$ & 10 & 6 & -4 & 0,2 & 0,2 & 0,1 \\
\hline \multicolumn{8}{|c|}{ Product within the strategic distribution zone "Distribution". } \\
\hline -range & Number of positions & 60 & 60 & 0 & 1 & 1 & 1 \\
\hline -production & Pre-ordering in SSU & 100 & 109 & +9 & 0,6 & 0,6 & 0,7 \\
\hline -packaging & $\begin{array}{l}\text { Evaluation of attractiveness, } \\
\text { recognition, convenience } \\
\text { (design for services) according } \\
\text { to the results of a consumer } \\
\text { survey, in } \%\end{array}$ & 100 & 96 & -4 & 0,2 & 0,2 & 0,1 \\
\hline -brand & $\begin{array}{l}\text { Recognition in\% of the survey } \\
\text { results }\end{array}$ & 100 & 85 & +15 & 0,6 & 0,6 & 0,5 \\
\hline -ecology & $\begin{array}{l}\text { Distributor survey on the } \\
\text { importance } \\
\text { implementation of quality and } \\
\text { environmental standards, in } \%\end{array}$ & 60 & 60 & 0 & 0,2 & 0,2 & 0,2 \\
\hline -coating & Number of distributors on site & 100 & 79 & -21 & 0,8 & 0,8 & 0,6 \\
\hline
\end{tabular}

** Top products / services are products or services that have the largest share in the sales basket of a small business in a certain period. Traditionally, for each company in a stable marketing environment, it does not change.

Developed by the author based on the data of the company Mavis Global LLC

As the analysis showed, the forecast indicator of the marketing efficiency of a small enterprise LLC Mavis Global is 10.9 points, and the actual indicator is 10.2 (there is a reserve for increasing the efficiency of marketing use -93.6\%). [15]

The paper shows the promising directions of formation and evaluation of the effectiveness of the implementation of a network marketing model in the field of entrepreneurship. The development was based on the $\mathrm{ABC}$ method, first used in network marketing. Borrowing the basics from logistics and product promotion, the method is based on the principle of forming a corresponding margin model and relationships with each distributor (the system includes the standard for categorizing retail outlets implemented in Mavis Global LLC). Further development and implementation of the network marketing model in the activities of Mavis Global LLC will contribute to a wider involvement in interaction with companies in product sales (NKA's key customers) and the growth of the company's competitiveness.

\section{Conclusion}

As a result of the dissertation research, the following conclusions and recommendations were made:

1. Disclosed are the methodological aspects of the formation of a marketing system in business, which made it possible to single out a comprehensive system of balanced and interdependent components in the form of conditions, resources and opportunities for marketing activities carried out by small business entities.

2. Identified the need for systemic marketing research based on the professional and periodic evaluation of the company and its marketing environment, goals, strategies, actions to identify problem areas, opportunities and recommendations for an action program to strengthen market positions and improve marketing activities.

3. A methodical approach was used to organize 


\begin{tabular}{|c|c|c|c|c|c|c|}
\hline \multirow{4}{*}{ Impact Factor: } & ISRA (India) & $=3.117$ & SIS (USA) & $=0.912$ & ICV (Poland) & $=6.630$ \\
\hline & ISI (Dubai, UAE & $=0.829$ & РИНЦ (Russia) & $=0.156$ & PIF (India) & $=1.940$ \\
\hline & GIF (Australia) & $=0.564$ & ESJI (KZ) & $=8.716$ & IBI (India) & $=4.260$ \\
\hline & JIF & $=1.500$ & SJIF (Morocco & $=5.667$ & OAJI (USA) & $=0.350$ \\
\hline
\end{tabular}

the collection of marketing information for the development of an entrepreneurship system in the Republic of Uzbekistan with the formation of a unified database and it was determined that it is an important tool for choosing a strategy for developing small business entities with defining strategic business areas $(\mathrm{SZH})$.

4. Comprehensive strategic analysis of the institutional framework for the level of development of marketing activities of small business in the Republic of Uzbekistan showed the fragmentation of statistical information and the lack of a generally accepted method of marketing research for the development of a small business system.

5. Identified features of the organization of marketing research in the field of entrepreneurship, taking into account survey methods, developed organizational and economic mechanisms for developing a marketing strategy in the field of entrepreneurship in the context of the formation of an innovative economy, promising directions for forming and evaluating the effectiveness of introducing the marketing mix in the business system.

6. Based on the factor analysis, methodical bases for monitoring the confectionery market and the capabilities of small businesses to meet customer needs have been developed, which includes the development of an assortment product line for Mavis Global LLC, which should be the basis for developing a marketing strategy for the company.

7. An integrated network marketing system of Mavis Global LLC was formed with a standard for sales outlet classification, including a relationship management system with each distributor, organization's Internet resources, as well as logistics automation and product marketing to the market (based on CRM systems research)

\section{References:}

1. Porter, M. (2011). Competitive Strategy: A Methodology for Analyzing Industries and Competitors / Trans. from English I. Minervina. (p.454). Moscow: Alpina Publisher.

2. Kotler, F. (2006). Marketing Management. Express course. 2nd ed. (p.464). SPb.: Peter.

3. Egan, J. (2006). Relationship Marketing: Analysis of Marketing Strategies Based on Peter, (p.464).

4. Egan, J. (2008). Relationship Marketing: An Analysis of Relationship Marketing Strategies. per. from English. (p.375). Moscow: UNITI.

5. Doyle, P. (2001). Cost-oriented marketing. by ed. Yu.N. Kapturevsky (Eds.). per. from English (p.480). SPb.: Peter.

6. Malhotra, N. K. (2002). Marketing research..Practical guidance. 3th edition. Per.sangl. (p.960). Moscow: Williams.

7. Afans'ev, M. P. (2015). Marketing: the strategy and practice of the company. (p.112). Moscow: AO Finstatypform.

8. Belyaev, V. I. (2010). Marketing: fundamentals of theory and practice. textbook. 4th ed., Pererab. and add. (p.680). Moscow: KNORUS.

9. Nosova, N. S. (2010). Competitive strategy of the company. Marketing methods of competition / 2nd ed. (p.256). Moscow: Dashkov and K0.

10. Godin, A. M. (n.d.). Methodological aspects of improving the modern theory of marketing in order to solve the problems of small.

11. Tursunov, B. O. (2017). Metody otsenki ekonomicheskoy nadezhnosti tekstil"nogo predpriyatiya $v$ usloviyakh rynochnoy ekonomiki. V sbornike: Teoriya i praktika organizatsii promyshlennogo proizvodstva. Effektivnost' organizatsii i upravleniya promyshlennymi predpriyatiyami: problemy $\mathrm{i}$ puti resheniya Materialy Mezhdunarodnoy nauchno-prakticheskoy konferentsii. (pp.139144). Voronezhskiy gosudarstvennyy tekhnicheskiy universitet.

12. Tursunov, B. O. (2017). Perspektivy razvitiya tekstil"noy promyshlennosti v uzbekistane. Menedzhment $v$ Rossii $i$ za rubezhom, № 4, 7884.

13. Tursunov, B. O. (2017). Strategiya razvitiya legkoy promyshlennosti respubliki uzbekistan. Vestnik Instituta ekonomiki Rossiyskoy akademii nauk, № 5, 146-155.

14. Tursunov, B. O. (2017). Principles and functions of management of production capacity. Voprosy upravleniya, № 3 (46), 174-178.

15. Tursunov, B. O. (2017). Metody otsenki ekonomicheskoy nadezhnosti tekstil"nogo predpriyatiya $v$ usloviyakh rynochnoy ekonomiki. V sbornike: Teoriya i praktika organizatsii promyshlennogo proizvodstva. Effektivnost' organizatsii i upravleniya promyshlennymi predpriyatiyami: problemy $\mathrm{i}$ puti resheniya Materialy Mezhdunarodnoy nauchno-prakticheskoy konferentsii. (pp.139144). Voronezhskiy gosudarstvennyy tekhnicheskiy universitet.

16. (n.d.). Kompaniya OOO «Mavis Global». Ofitsial'nyy sayt [Elektronnyy resurs]. Retrieved 2019, from https://mavis.all.biz/group-goods 